\title{
TecNologia na educaÇão
}

Joly, M. C. R. A. (org.) 2002. A tecnologia no ensino: implicações para a aprendizagem. São Paulo: Casa do Psicólogo, 162 p.

A tecnologia no ensino: implicações para aprendizagem discute a tecnologia na educação como um recurso estratégico voltado para uma ação pedagógica diferenciada. Ao longo da leitura é possível perceber, em seus seis capítulos, o importantíssimo papel atribuído ao professor para a implantação desses novos recursos tecnológicos no contexto educacional, frente ao desenvolvimento da sociedade informatizada.

O primeiro capítulo do livro foi escrito por J. A. Valente e retrata as mudanças ocorridas nas funções desempenhadas pelo computador no processo de aprendizagem ao longo destas últimas duas décadas. Relata que, no Brasil, questiona-se muito a validade do uso de recursos tão dispendiosos em face das necessidades e prioridades básicas da educação. A idéia de espiral é usada pelo autor para explicar o processo de construção do conhecimento na interação aprendiz - computador, citando a internet como um bom exemplo por revelar a ocorrência de aprendizagem em espiral , associando a esse processo os aspectos emocionais e sociais.

O desafio da escola frente à inserção da tecnologia da informação em seu contexto foi descrito por S. P. Marinho no segundo capítulo. Abandonar a idéia de deter o monopólio do conhecimento e assumir mudanças nas ações educativas a partir de um trabalho coletivo de todos os profissionais da escola, destacando-se dentre eles os professores, é o primeiro desafio a ser enfrentado. Nessa perspectiva, analisa o papel do computador como um agente mediador de relações e comunicações que traz, para o espaço da aprendizagem, a informação e o conhecimento que agora estão disponíveis nas redes.

M. A. Silveira e M. C. R. A. Joly discutem, no terceiro capítulo, a influência da globalização no contexto educacional, apontando para a necessidade de formação de profissionais comprometidos com sua realidade e competentes para solucionar problemas criativamente. Para tanto, há que utilizar-se de recursos que propiciem um ensino com muito mais flexibilidade, processos mais abertos de pesquisa e de comunicação e menos conteúdos fixos. A internet disponibilizou a tecnologia da informação a um grupo imenso de pessoas, mas percebe-se, que embora possua um vasto potencial educativo, às vezes é subutilizada, ignorando-se seu aspecto instrutivo.

As informações trazidas no quarto capítulo, por D. N. Montero e A. M. Ruiz, abordam a tecnologia da informação e da comunicação que está transformando a configuração tradicional do trabalho, ampliando seus horizontes e potencializando-os, como uma revolução sociocultural. Faz-se necessário, portanto, favorecer a formação tecnológica do professor, a criação de conteúdos educativos para a internet e a conexão de todos centros educativos na rede com infraestrutura mais avançada para assegurar o uso dessa tecnologia.

No quinto capítulo, a autora M. C. R. A. Joly destaca pesquisas desenvolvidas sobre leitura e escrita usando-se o computador como estratégia de ensino que identificaram, a partir de seus resultados, uma nova relação entre professores e alunos com o processo de aprendizagem, com o conhecimento resultante e as diferentes formas de ensinar e aprender.

O último e sexto capítulo, escrito por J. F. B. Lomônaco, apresenta o concept-set como uma tecnologia educacional não informatizada, que possibilita o aprendizado de conceitos em sala de aula, a partir dos princípios e conceitos da teoria behaviorista. Questiona, dessa forma, a necessidade do uso único de recursos informatizados num processo de aprendizagem eficaz.

Constituído pela colaboração de vários docentes e profissionais de áreas diversificadas, este trabalho traduz a convergência de estudos e pesquisas realizados sobre o tema, intimamente ligado à evolução da comunicação humana e dos processos de informação. Muito bem discutido e analisado, o livro resenhado consiste em um instrumento de reflexão e informação útil para docentes, pesquisadores e todos aqueles que se interessarem pelo assunto abordado, uma vez que traz para o contexto educacional a possibilidade de uma aproximação entre a tecnologia e o processo de ensino-aprendizagem, viabilizando uma prática pedagógica renovada.

\section{Lucicleide Maria de Cantalice Universidade São Francisco}

